origin, or with phase difference $=0$. If the slit be in- $/$ sponding to phase-difference $=\frac{1}{2}$. It is easy then to clined in the opposite direction the quality is that corre- examine whether or not the effect of these differences of

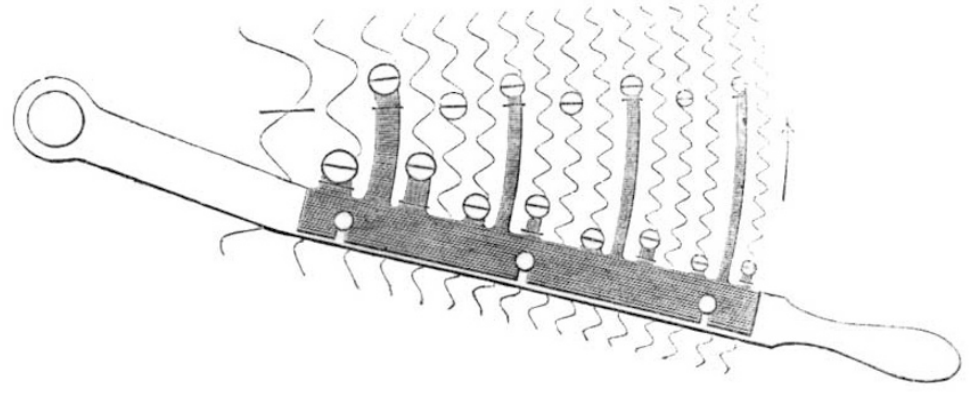

Fig. 8.-Position of the slits for phase-difference 0 .

phase on the ear is the same, by merely inclining the slit forward or backward. Kœnig finds invariably a purer and more perfect sound with phase-difference $=0$, and $a$

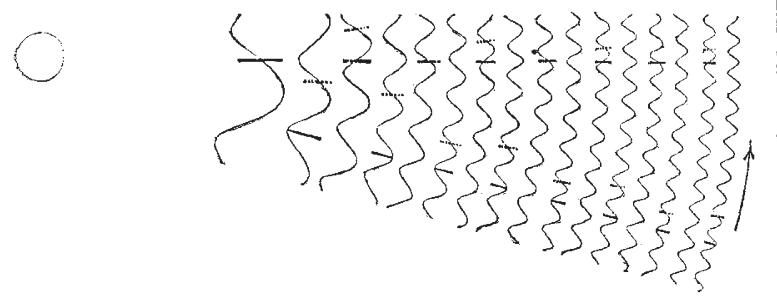

Fig. 9.-Position of the slits for phase-difference $\frac{1}{2}$.

more strident and nasal sound with phase-difference $=\frac{1}{2}$. This result is so easy to verify that it will doubtless be tried by many experimenters. Indeed many of the re-

\section{HONOUR TO M. PASTEUR}

$A \mathrm{~T}$ the séance of the Paris Academy of Sciences on A the 26 th ult., the President (M. Jamin) stated that Pasteur having resolved to present him with a medal commemorative of his remarkable discoveries, a committee had been appointed to watch the execution of it. On completion of the work, this committee, on June 25 , repaired to M. Pasteur's house to present the medal, which is the design of M. Alphée Dubois, and happily recalls the physiognomy of its distinguished recipient. The meeting included MM. Dumas, Boussingault, Bouley, Jamin, Bertin, Tisserand, Davaine, and others. On this occasion M. Dumas delivered an address, in which he recalled the labours of M. Pasteur; and after receiving the medal, M. Pasteur made a few observations in reply, The two speeches have been, on the suggestion of $M$. Thenard, inserted in Comptes rendus, and we here reproduce them, in translation. M. Dumas said :-

"MY DEAR PASTEUR,-Forty years ago you entered this house as a student. From the first your teachers foresaw that you would be an honour to them; but none would have ventured to predict what brilliant services you were destined to render to science, to the country, and to the world.

"Your earliest labours banished occult forces for ever from the domain of chemistry, by explaining the anomalies of tartaric acid.

"Confirming the vital doctrine of alcoholic fermentation, you extended this doctrine of French chemistry to the most diverse fermentations, and you gave to the manu- searches with the wave-disks are so easily repeated without any special or expensive apparatus that they will

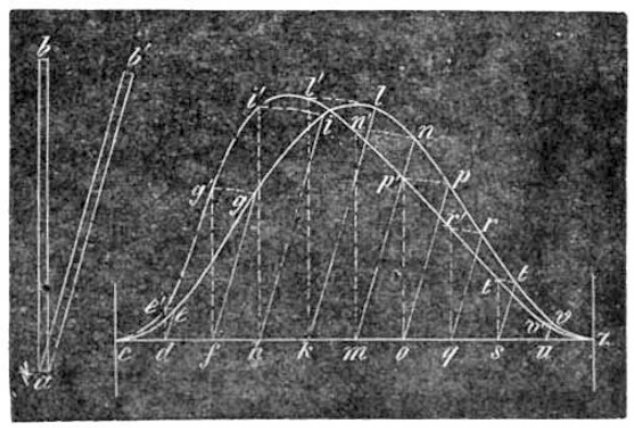

FIG. 10.--Effect of inclining the slit.

surely win a place amongst the familiar experiments of acoustics.

facture of vinegar, rules which industry now applies with thankfulness.

"Among these infinitely minute living things you dis. covered a third kingdom, to which those beings belong which, with all the prerogatives of animal life, do not need air to live, and which find the heat they require in the chemical decompositions they excite around themselves.

"The profound study of ferments gave you the complete explanation of alterations undergone by organic substances-wine, beer, fruits, animal matters of all kinds ; you explained the preservative rôle of heat applied to their conservation, and you learned to regulate the effects of it according to the temperature necessary to cause the death of ferments. Ferments when dead produce ferments no more.

"It was thus that you were led to maintain throughout the extent of the organic kingdoms the fundamental principle according to which life is derived from life, and which rejects as a useless and unfounded supposition the doctrine of spontaneous generation.

"It is thus that, showing air to be the vehicle of the germs of most ferments, you learned to preserve without alteration the most putrescible matters, by keeping them from all contact. with impure air.

"Applying this idea to the alterations, so often fatal, to which wounds and sores are liable when the patients inhabit a contaminated place, you learred to guard them from this danger by surrounding their limbs with filtered air, and your precepts, adopted by surgical practice, daily insure to it successes it knew not before, and give its operations a boldness of which our predecessors had no presentiment. 
"Vaccination was a beneficent practice. You have discovered its theory and enlarged its applications. You have learned how to produce vaccine matter from a virus; how a fatal poison becomes a harmless preservative. Your researches on anthracoid disease, and the practical consequences from them, have rendered to agriculture a service of which all Europe feels the value. But the results already obtained, however brilliant, are nothing in comparison with the applications which may be anticipated from the doctrine to which they are due. You have furnished a sure basis to the doctrine of viruses by associating it with the theory of ferments; you have opened a new era for medicine by proving that every virus may have its vaccine-matter.

"Amid these admirable conquests of pure science, natural philosophy, and practice, we might forget that there is one part of the country where your name is pronounced with particular respect-the country once so fortunate, where the silkworm is cultivated. A malady which had spread terror among all the families of our southern mountains had destroyed the fine races they had produced with much care and wise selection. The ruin was complete. Now, thanks to your processes of scientific grainage, the cultivators have regained their security, and the country sees one of its sources of wealth reviving.

"My dear Pasteur, your life has only known successes. The scientific method, of which you make such certain use, owes you its finest triumphs. The Normal School is proud to count you among the number of its students; the Academy of Sciences is elated at your researches; France ranks you among her glories.

"At a time when, from all parts, testimonies of the public gratitude are arising towards you, the homage we come to offer you in name of your admirers and your friends, may seem to you worthy of special attention. It emanates from a spontaneous and universal sentiment, and it preserves for posterity the faithful image of your features.

"May you, my dear Pasteur, long enjoy your honour, and contemplate the fruits, ever richer and more numerous, of your labours. Science, agriculture, industry, humanity, will feel eternal gratitude to you, and your name will live in their annals among the most illustrious and the most venerated."

\section{Pasteur replied as follows :-}

"MY DEAR TEACHER,--It is forty years, indeed, since $I$ had the good fortune to make your acquaintance, and since you taught me to love science and honour.

"I came from the provinces; after each of your lectures, I went out from the Sorbonne, transported, and often moved even to tears. From that time, your talent as professor, your immortal works, your noble character, have inspired me with an admiration which has only increased with the maturity of my mind.

"You must have divined my sentiments, my dear Teacher. There is not a single important circumstance of my life or of that of my family, circumstance bappy or painful, which has found you absent, and which you have not, in some sort, blessed.

"And here you are still among the foremost in expres sion of these testimonies, excessive truly in my opinion, of the esteem of my teachers, who have become my friends.

"And what you have done for me you have done for all your students. It is one of the distinctive traits of your nature. Behind individuals you have always contemplated France and her greatness.

"What shall I do henceforth? Hitherto great eulogia had inflamed my ardour, and only inspired the idea of rendering myself worthy of them by new efforts; but those which you have addressed to me, in name of the Academy and of learned societies, truly overpower me."

\section{NOTES}

THE Council of the Society of Arts have elected C. W. Siemens, D.C.L., LL.D., F.R.S., as Chairman for the ensuing year.

IT has now been definitely decided to build a permanent observatory on Ben Nevis.

IT is announced that the Duke of Bedford haz given 5000: for the endowment of a lectureship in physical science at Balliol College, Oxford.

Dr. George Dickie, ex-Professor of Botany in the University of Aberdeen, died at Aberdeen on Saturday morning. The deceased, who was a native of Aberdeen, and was educated at Marischal College, was for some time in practice in the city as a doctor and dispensing chemist. His tastes, bowever, lay very markedly in the line of botanical research. He held the Botanical Chair in the Queen's College, Belfast, for a number of years, and on the fusion of King's College and Marischal College into one Aberdeen University he was appointed Professor of Botany. He discharged the duties for seventeen years, only resigning in 1877 on account of impaired health. Dr. Dickie had written numerous papers, and published some books connected with his favourite study, these including "A Handbook of Flora of Aberdeenshire," which was subsequently supplemented by a much larger volume, "The Botanist's Guide," published in 1860 . His favourite department of botanical study was Algre. On the return of the Challenger expedition he was, for the purposes of study, supplied with the Algce collected during the cruise.

LET us draw the attention of local natural history societies to the prospectus of the forthcoming International Fisheries Exhibition. On some points these societies might be able to render material aid to the Conmissioners, who, we believe, are desirous of enlisting their co-operation. Indeed, all of our readers interested in such an exhibition should procure copies of the prospectus by applying to the Secretary, 24, Haymarket, London, S.W. The Exhibition will cover a very wide field, and therefore appeals to a great variety of interests.

Prof. A. Smith of the Swedish National Museum, who has been delegated as the representative of Sweden at the Fishery Exhibition in London next year, has commissioned Dr. A. Malm to prepare a collection of the sea fish species of the west coast of Sweden, to be forwarded at the expense of the museum. Dr. Malm will also arrange the collection which the Gothenburg Museum will exhibit, Mr. O. Dickson having offered to defray the expenses thereof. Mr. Dickson has been chosen as the "honorary correspondent" of Sweden at the exhibition.

THE Sydney Morning Herald justly animadverts in strong terms on the geography in some of the school books in common use in New South Wales, under the sanction of the government. These are published by a well-known Glasgow firm, and no attempt has been made to adapt them either to the conditions of the Southern Hemisphere, or to recent knowledge. The Herald gives some choice examples of the "facts" taught to the rising generation at the Antipodes. "At twelve o'clock," the book tells us, "in the day, when you go out to play, if you look at the part of the sky where the sun is shining, that part is called the south; then turn and look behind you, where the sun never comes, that is the north, it is opposite the south." Again, "the country you live in is Ireland; it is called an island because it has water all round it, and is not joined to any other country ;" the Herald states, "and this has been taught to Australian children, at the expense of the public of New South Wales, for the last thirty or forty years." In a chapter headed "Australasia," there is the following passage :- "The name of Austral 